\title{
Cobalamin cbiP mutant shows decreased tolerance to low temperature and copper stress in Listeria monocytogenes
}

\author{
L. Vásquez ${ }^{1}$, A. Parra ${ }^{2,3}$, A. M. Quesille-Villalobos ${ }^{1}$, G. Gálvez ${ }^{4}$ P. Navarrete ${ }^{1,5}$, M. Latorre ${ }^{4,6}$, M. Toro ${ }^{1}$, \\ M. González ${ }^{6,7}$ and A. Reyes-Jara ${ }^{1 *}$ (D)
}

\begin{abstract}
Background: Listeria monocytogenes is a foodborne pathogen that causes listeriosis in humans. This pathogen activates multiple regulatory mechanisms in response to stress, and cobalamin biosynthesis might have a potential role in bacterial protection. Low temperature is a strategy used in the food industry to control bacteria proliferation; however, L. monocytogenes can grow in cold temperatures and overcome different stress conditions. In this study we selected L. monocytogenes List2-2, a strain with high tolerance to the combination of low temperature + copper, to understand whether the cobalamin biosynthesis pathway is part of the tolerance mechanism to this stress condition. For this, we characterized the transcription level of three cobalamin biosynthesis-related genes (cbiP, cbiB, and cysG) and the eutV gene, a transcriptional regulator encoding gene involved in ethanolamine metabolism, in L. monocytogenes strain List2-2 growing simultaneously under two environmental stressors: low temperature $\left(8^{\circ} \mathrm{C}\right)+\operatorname{copper}$ $\left(0.5 \mathrm{mM}\right.$ of $\left.\mathrm{CuSO}_{4} \times 5 \mathrm{H}_{2} \mathrm{O}\right)$. In addition, the gene cbiP, which encodes an essential cobyric acid synthase required in the cobalamin pathway, was deleted by homologous recombination to evaluate the impact of this gene in L. monocytogenes tolerance to a low temperature $\left(8^{\circ} \mathrm{C}\right)+$ different copper concentrations.
\end{abstract}

Results: By analyzing the KEGG pathway database, twenty-two genes were involved in the cobalamin biosynthesis pathway in L. monocytogenes List2-2. The expression of genes cbiP, cbiB, and cysG, and eutV increased $6 \mathrm{~h}$ after the exposure to low temperature + copper. The cobalamin cbiP mutant strain List2-2 $\triangle$ cbiP showed less tolerance to low temperature + copper ( $3 \mathrm{mM}$ ) than the wild-type L. monocytogenes List2-2. The addition of cyanocobalamin (5 $\mathrm{nM}$ ) to the medium reverted the phenotype observed in List2-2 $\triangle$ cbiP.

Conclusion: These results indicate that cobalamin biosynthesis is necessary for L. monocytogenes growth under stress and that the cbiP gene may play a role in the survival and growth of L. monocytogenes List2-2 at low temperature + copper.

Keywords: Listeria monocytogenes, Copper, Cobalamin, Low temperature

*Correspondence: areyes@inta.uchile.cl

1 Laboratorio de Microbiología y Probióticos, INTA Universidad de Chile, Avenida El Líbano 5524 Macul, Santiago, Chile

Full list of author information is available at the end of the article

\section{Background}

Foodborne diseases are a significant cause of morbidity and mortality worldwide, and they are considered a major public health problem [1-3]. One of the most relevant foodborne pathogens is Listeria monocytogenes, a ubiquitous microorganism [4-6]. L. monocytogenes causes listeriosis in humans, a disease acquired through the ingestion of contaminated food. Listeriosis original author(s) and the source, provide a link to the Creative Commons licence, and indicate if changes were made. The images or other third party material in this article are included in the article's Creative Commons licence, unless indicated otherwise in a credit line to the material. If material is not included in the article's Creative Commons licence and your intended use is not permitted by statutory regulation or exceeds the permitted use, you will need to obtain permission directly from the copyright holder. To view a copy of this licence, visit http://creativecommons.org/licenses/by/4.0/. The Creative Commons Public Domain Dedication waiver (http://creativeco mmons.org/publicdomain/zero/1.0/) applies to the data made available in this article, unless otherwise stated in a credit line to the data. 
can range from febrile gastroenteritis to severe invasive disease; it primarily affects neonates, the immunosuppressed, pregnant women, and the elderly, reaching mortality rates up to $30 \%[5,7]$.

Listeria monocytogenes can survive and grow under diverse stress conditions; it can tolerate and adapt to high $\mathrm{NaCl}$ concentrations ( $\geq 10 \%$ ), a wide range of $\mathrm{pH}$ (4.5-9.0), and several sanitizers [4, 8, 9]. L. monocytogenes can grow at temperatures as low as $-1{ }^{\circ} \mathrm{C}$ [8]. The pathogen has been isolated from soil, silage, seawater, estuarine water, surface waters, and most importantly, food processing facilities and diverse food matrices [10-14]. The genetic characteristics of $L$. monocytogenes and the regulation of the transcriptional response are the main reasons why this bacterium survives in a wide range of environmental conditions [5, $15,16]$.

Cobalamin-vitamin B12-is a water-soluble vitamin synthesized by bacteria and archaea [17]. As a nutrient, cobalamin acts as a cofactor for methyltransferases, isomerases, and dehalogenases, all enzymes involved in several essential biochemical processes such as carbon source fermentation and ribonucleotide reduction [18, 19]. Cobalamin and its derivatives are involved in the fermentation of small molecules such as 1,2-propanediol and ethanolamine [20]. Cobalamin biosynthesis is a complex process; more than thirty genes have been linked to its biosynthesis. Reports indicate that only a few bacteria and archaea can synthesize this molecule [21, 22]. De novo biosynthesis occurs as an anaerobic process in archaea and aerobic/anaerobic in bacteria [23, 24].

Ferrer et al. described that cobalamin acts as an antioxidant agent in Leptospirillum [25]. This iron-oxidizing bacterium belongs to the phylum Nitrospirae and grows in highly acidic and metal-loaded environments. When Leptospirillum was exposed for $1 \mathrm{~h}$ to oxidative stress conditions $\left(\mathrm{Fe}_{2}\left(\mathrm{SO}_{4}\right)_{3}, \mathrm{H}_{2} \mathrm{O}_{2}\right.$ or $\left.\mathrm{K}_{2} \mathrm{CrO}_{4}\right)$, intracellular reactive oxygen species (ROS) increased significantly; however, when the bacterium's growth medium was supplemented with cobalamin before the stress, ROS levels remained at basal level [25]. L. monocytogenes can also grow under different stress conditions, such as the acidic $\mathrm{pH}$ used as a strategy to control bacterial growth along the food chain [14]. It has been described that cobalamin, 1,2-propanediol, and ethanolamine may help L. monocytogenes survive in food and food production environments [26, 27]. A global transcriptional study of L. monocytogenes growing in vacuum-packed salmon at $7{ }^{\circ} \mathrm{C}$ versus modified brain-heart infusion broth at $7{ }^{\circ} \mathrm{C}$ revealed that 149 genes changed their expression. Among the up-regulated genes $(n=88)$, twenty-six encoded proteins related to cobalamin biosynthesis, ethanolamine metabolism, and 1,2-propanediol [28].
New alternatives to control L. monocytogenes in the food industry have been explored. One strategy is using copper, which has antibacterial activity on different pathogenic bacteria [29-31]. Although copper has been described as an essential micronutrient that participates as an enzyme cofactor [32, 33], its intracellular level is strictly regulated because its excess is toxic $[34,35]$. We previously observed that the antibacterial effect of copper in L. monocytogenes was enhanced at low temperatures [35] and we determined that the minimal inhibitory concentration of copper at $37{ }^{\circ} \mathrm{C}$ was $10-12 \mathrm{mM}$ and at $8{ }^{\circ} \mathrm{C}$ was $4-6 \mathrm{mM}$ of $\mathrm{CuSO}_{4} \times 5 \mathrm{H}_{2} \mathrm{O}$ [36].

We analyzed the proliferation rate of different strains of $L$. monocytogenes and identified that the List2-2 strain had the highest growth rate at $8{ }^{\circ} \mathrm{C}$ [37]. This strain was the least affected by the combination of low temperature + copper according to their growth kinetic parameters [36]. List2-2 was selected to evaluate the effect of the global transcriptional response to low temperature and copper. This strain modified the expression of 263 genes in response to a sub-inhibitory copper concentration $\left(0.5 \mathrm{mM}\right.$ of $\left.\mathrm{CuSO}_{4} \times 5 \mathrm{H}_{2} \mathrm{O}\right)+$ low temperature $\left(8{ }^{\circ} \mathrm{C}\right)$, including some genes encoding for proteins involved in the cobalamin biosynthesis pathway [36]. Based on this information, we hypothesized that cobalamin biosynthesis was involved in the tolerance of $L$. monocytogenes List2-2 to the simultaneous exposure to low temperature $\left(8{ }^{\circ} \mathrm{C}\right)+$ copper $(0.5 \mathrm{mM})$ as a stress condition. In this study, we identified genes involved in cobalamin biosynthesis by analyzing the KEGG database and quantified the abundance of transcripts for genes associated with this pathway at $8{ }^{\circ} \mathrm{C}+$ copper over time. Finally, we mutated $c b i P$, which encodes for a cobyric acid synthase involved in the cobalamin biosynthesis, and studied the mutant's phenotype.

\section{Results \\ Genes involved in the cobalamin biosynthesis in $L$. monocytogenes List2-2}

All the elements described for cobalamin biosynthesis in L. monocytogenes EGD-e were identified in List2-2 (Additional file 1: Fig. S1), and we identified 22 cobalamin biosynthesis genes. All 22 genes showed 100\% identity with those described in the L. monocytogenes EGD-e strain in the KEGG database. Two upstream genes of the cobalamin biosynthetic pathway were located in the same strand as an operon responsible for the metabolism of 1,2-propanediol. The transcriptional regulator encoding gene eut $V$ was also identified; this gene is responsible for the transcription of the ethanolamine operon and is regulated by cobalamin. 
Expression pattern of cobalamin-related genes in $L$. monocytogenes under simultaneous exposure to low temperature + copper

We selected three genes involved in cobalamin biosynthesis to evaluate their transcriptional response to low temperature $\left(8{ }^{\circ} \mathrm{C}\right)+\operatorname{copper}(0.5 \mathrm{mM})$ simultaneously at different times of exposure (Fig. 1). The genes $l$ mo1201 (cysG), lmo1208 (cbiP) and lmo1192 (cbiB) were chosen based on their genome location in the cobalamin biosynthesis gene cluster and for being involved in the first and last stages of cobalamin biosynthesis (Additional file 1: Fig. S1). We observed that the relative expression of the genes did not change after $1 \mathrm{~h}$ of simultaneous exposure at $8{ }^{\circ} \mathrm{C}+$ copper $(0.5 \mathrm{mM})$ compared to the control $\left(8^{\circ} \mathrm{C}\right.$, no copper). A significant increase in the relative expression was observed for the genes $c y s G, c b i P$, and $c b i B$ at $6 \mathrm{~h}$ after copper exposure, but this expression decreased after $24 \mathrm{~h}$ of exposure at the level of $1 \mathrm{~h}$. Interestingly, cbiP presented 4.5 times the abundance of transcripts of the control at $6 \mathrm{~h}$. The gene eutV, a transcriptional regulator of ethanolamine metabolism, presented the same expression pattern observed for $c b i P$, with a significant increase at $6 \mathrm{~h}$ of exposure and a reduction at $24 \mathrm{~h}$ (Fig. 1D).

\section{L. monocytogenes List2-2 $\Delta$ cbiP showed lower tolerance to low temperature + copper}

To evaluate the importance of genes encoding for cobalamin biosynthesis in copper tolerance at low temperature, we deleted the gene $c b i P$ by homologous recombination. As a result, List2-2 $\triangle c b i P$ did not grow in agar media supplemented with $3 \mathrm{mM}$ of copper at $8{ }^{\circ} \mathrm{C}$, while the wild-type strain proliferated under the same condition (Fig. 2A). This result suggests that List2-2 $\Delta c b i P$ is more sensitive to copper at low temperature than the wild-type strain on a solid medium. To evaluate the effect of cobalamin on the mutant, we supplemented the medium with cyanocobalamin (the active form of cobalamin). In this condition, List2-2 $\Delta c b i P$ was able to grow at $3 \mathrm{mM}$ copper cultured at $8{ }^{\circ} \mathrm{C}$ in the solid medium, demonstrating that $5 \mathrm{nM}$ of cyanocobalamin improved List2-2 $\Delta c b i P$ survival cultured at low temperature + copper (Fig. 2B).
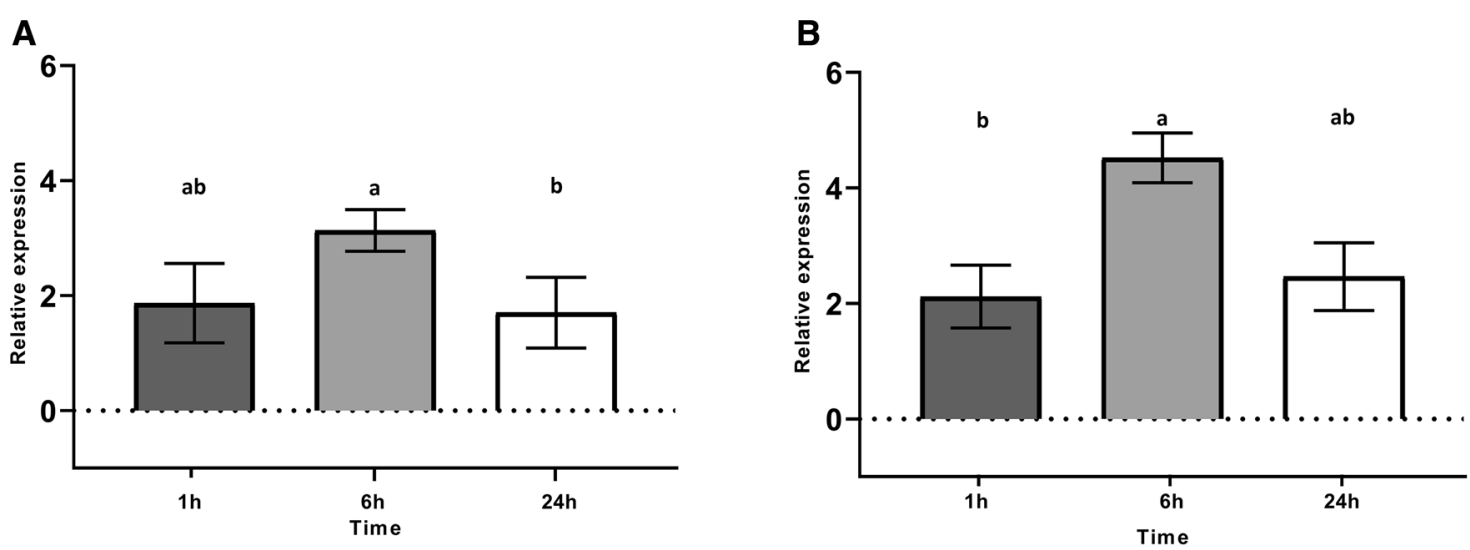

C

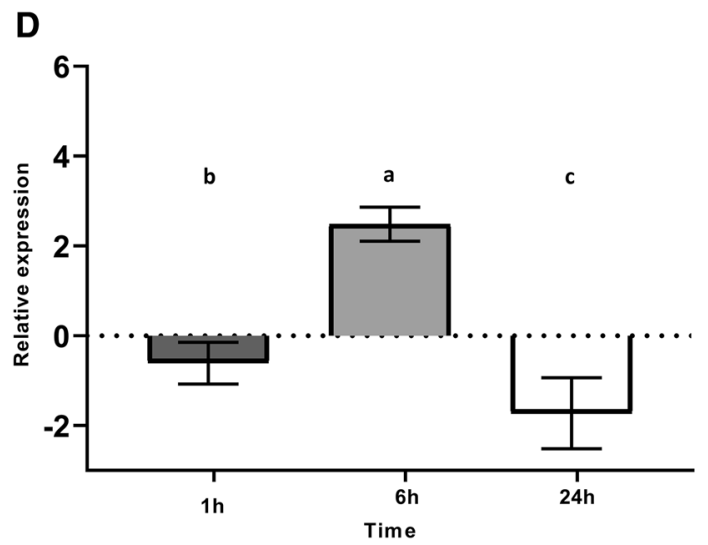

Fig. 1 Temporal expression pattern of cobalamin biosynthesis-related genes in response to copper $(0.5 \mathrm{mM})$ of L. monocytogenes List2-2 growing at $8^{\circ} \mathrm{C}$. A cys G, B cbiP, C cbiB, D eutV. Data were expressed as fold-change between copper treated at different times and untreated (time zero without copper). Different letters indicate significant differences comparing different times (1, 6 and 24 h). $P$-value: $<0.05$ 


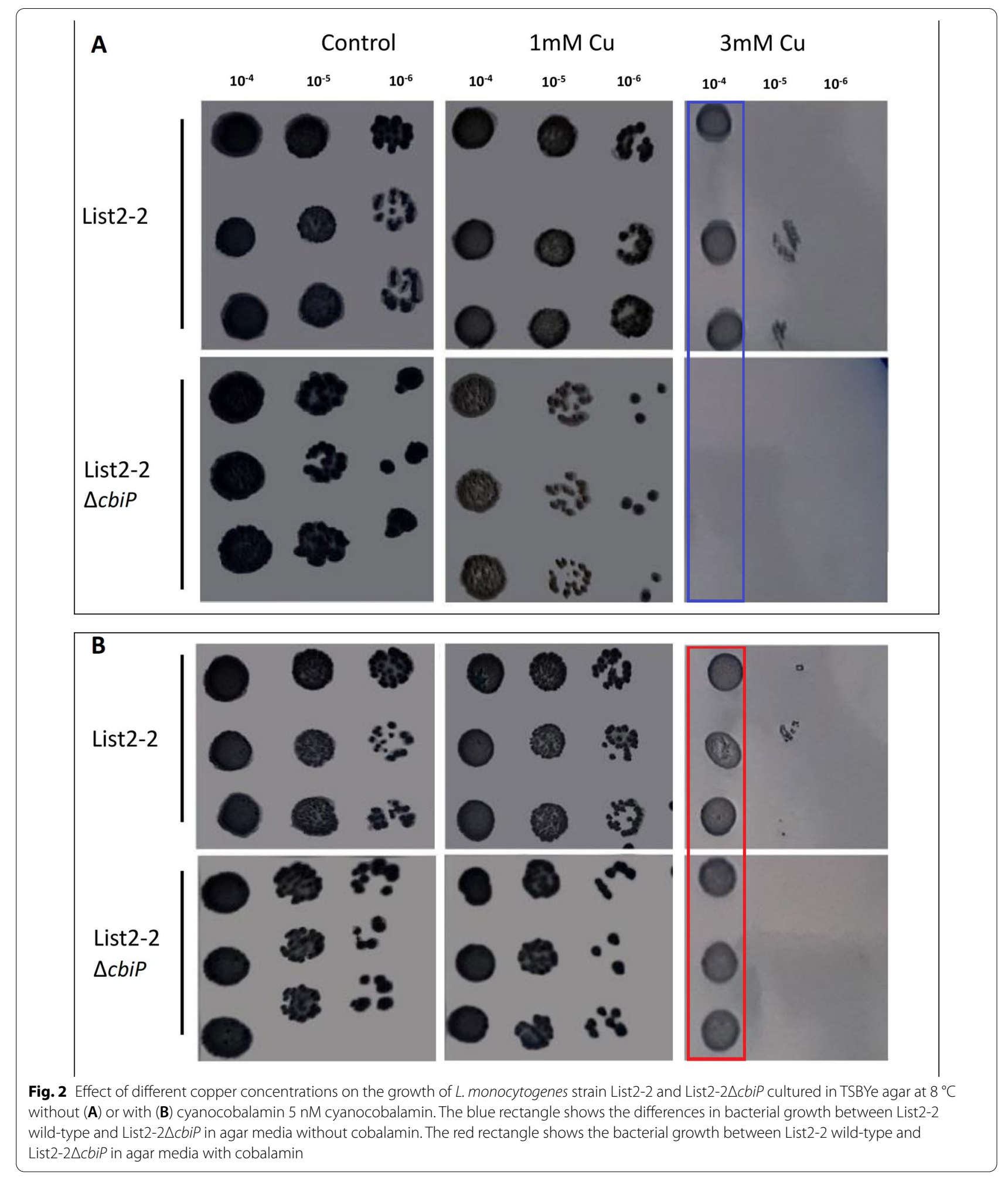

\section{Discussion}

One of the mechanisms that microorganisms use to respond to external stimuli is by modifying the expression of genes that encode proteins that allow them to adapt to new environments. The ability of L. monocytogenes to multiply at low temperatures and tolerate 
different stress factors is a consequence of the diversity of genetic elements that it encodes in its genome and the regulation that controls the expression of these elements. Among these components are elements that code for cobalamin synthesis, a cofactor that participates in different metabolic processes and plays a fundamental role in the pathogen's survival under stress conditions [38].

Cobalamin is synthesized by certain bacteria and archaea, but not by plants or animals; in higher organisms, the requirements of this vitamin are covered by interactions between microorganisms, plants, and animal tissues that are part of the food chain $[38,39]$. It has been proposed that the evolution of the cyanocobalamin synthesis pathway allowed the fermentation of small molecules such as ethanolamine, 1,2-propanediol, and glycerol in anaerobic environments [20]. De novo cobalamin synthesis occurs in bacteria and archaea, and some species also may synthesize cobalamin by absorbing corrinoids through the salvage pathway [40].

The genes involved in cobalamin biosynthesis in $L$. monocytogenes are conserved [26]. The genome sequence analysis of List 2-2 strain allowed us to identify the 22 genes previously described involved in the anaerobic pathway of cobalamin biosynthesis. We have observed that the growth of L. monocytogenes in low temperature and copper activates mechanisms in response to stress that allow the bacterium to tolerate these conditions [36, 37]. Recently, Ahn et al. [41] observed that cobalamin biosynthesis acted as a protective mechanism against the oxidative stress generated by cold in Thioalkalivibrio spp. (haloalkaliphilic chemolithoautotrophic sulfur-oxidizing) growing at low temperature $\left(10{ }^{\circ} \mathrm{C}\right)$. It has been reported that cobalamin biosynthesis genes increase their expression in response to arsenic, highlighting the antioxidant activity of this vitamin against metal stress [42].

Information about the relationship between cobalamin and the stress response in L. monocytogenes is limited. Studies reporting L. monocytogenes exposed to quaternary ammonium compounds reported a significant increase in expression for cobalamin genes [43]. Similar effects were detected when L. monocytogenes was coldstressed under vacuum conditions [28]. Recently, transcriptomics of $L$. monocytogenes co-cultured with cheese rind bacteria revealed that genes of the ethanolamine, 1,2-propanediol, and cobalamin metabolism were upregulated, showing that these genes were fundamental in a competitive environment against other bacteria [27].

Previously we had observed that the transcriptional response of $L$. monocytogenes differed when stress factors were presented separately or together. In particular, exposure of List2-2 to low temperature + copper activated different cellular processes from those regulated by cold or copper [36]. In this study, we observed an increase in the expression of genes associated with the cobalamin pathway when L. monocytogenes was cultured at different times at low temperatures with copper in aerobic conditions. This observation could indicate that $L$. monocytogenes require synthesizing cobalamin under this stress condition. It has been reported that in either an aerobic or anaerobic condition, the cobalamin genes in L. monocytogenes may increase their relative expression in response to stress [27, 44]. Moreover, eutV expression increased in response to copper at low temperature with a similar pattern to what was observed for genes related to cobalamin synthesis. This result concurs with the role of cobalamin as a cofactor for the riboswitch Rli55, which controls the expression of the eut genes [45].

Recent reports indicate that the deletion of $\operatorname{cobK}$, a gene that encodes a predicted precorrin-6A reductase, in Mycobacterium smegmatis affected cobalamin synthesis, suggesting that mutating one gene in the pathway affects cobalamin production [46]. Mutation of the gene cbiP $(\triangle c b i P)$ in Halobacterium reduced the archaeal growth in a medium deficient in corrinoids; however, when the medium was supplemented with cobyric acid, its growth ability was reestablished through reinstating the salvage pathway in the mutant strain [47].

CbiP is a synthase that catalyzes the synthesis of adenosyl-cobyric acid, a step that occurs almost at the end of the cobalamin biosynthesis pathway [48]. In this study, the gene cbiP of L. monocytogenes stressed by low temperature and copper showed high expression levels after $6 \mathrm{~h}$ at cold + copper. Deleting cbiP affected the growth of List-2-2 in a solid medium when bacteria were cultured at $8{ }^{\circ} \mathrm{C}+$ copper. The mutant reduced its growth with $1 \mathrm{mM}$ copper, and it was inhibited at $3 \mathrm{mM}$ copper compared to the wild-type strain. Supplementing the medium with cobalamin supported List2-2 $\Delta c b i P$ growth as observed in the wild-type strain. This implies that $L$. monocytogenes may be using cobalamin from the medium to supply the needs to survive stress.

\section{Conclusions}

These results suggest that cobalamin has a protective effect on the stress response of L. monocytogenes to cold and copper. Possible explanations may be that the antioxidant capacity of cobalamin helps to manage stress or that the lack of cobalamin would affect the ability of $L$. monocytogenes to metabolize other sources of energy (such as ethanolamine), affecting the survival of L. monocytogenes. Further studies to test these hypotheses and cobalamin concentrations in L. monocytogenes exposed to cold and copper will be helpful to elucidate the levels of vitamin required to protect against stress conditions. 


\section{Methods}

\section{Strains and culture conditions}

Listeria monocytogenes strain List2-2 (NCBI biosample ID: SAMN19838404) was isolated from seafood and is part of our repository. The isolate was confirmed as $L$. monocytogenes by PCR [49]. The tolerance of List2-2 to low temperature and copper had been previously studied [35-37]. For assays at low temperature, List2-2 was adapted as follows: the first day, a single colony was inoculated into Trypticase Soy Broth (BBL, Becton Dickinson, United States) containing 0.6\% yeast extract (Oxoid, Basingstoke, United Kingdom); TSBYe and cultured at $37^{\circ} \mathrm{C}$ overnight at $160 \mathrm{rpm}$. The next day, cold, fresh TSBYe broth was inoculated with L. monocytogenes and adjusted to an optical density of 0.05 at $600 \mathrm{~nm}\left(\mathrm{OD}_{600 \mathrm{~nm}}\right)$. The culture was grown at $8{ }^{\circ} \mathrm{C}(160 \mathrm{rpm})$ for $72 \mathrm{~h}$ at $160 \mathrm{rpm}$ to adapt it to low temperatures. For assays at $37{ }^{\circ} \mathrm{C}$, a single List2-2 colony was incubated in TSBYe at $37{ }^{\circ} \mathrm{C}$ (160 rpm) overnight. Microbiological assays were run in a biosafety level II-approved laboratory only accessible to trained individuals working with human foodborne pathogens.

\section{Identification of genes involved in the cobalamin pathway}

We selected the genes that encode for proteins involved in the cobalamin pathway using the information for $L$. monocytogenes EGD-e strain (ID: AL591824) reported in the KEGG PATHWAY database (Kyoto Encyclopedia of Genes and Genomes). Then we searched for these genes in the genome of L. monocytogenes List2-2 strain by alignment with the BLAST tool (http://www.ncbi.nlm. nih.gov/BLAST).

\section{Gene expression assays}

Three genes-lmo1201 (cysG), lmo1208 (cbiP), and lmo1192 (cbiB)-involved in cobalamin biosynthesis were selected considering their position in the cobalamin biosynthesis gene cluster: the beginning, middle, and end. These genes encode proteins involved in the first and last stage of cobalamin biosynthesis, stages that operate under aerobic conditions (Additional file 1: Fig. S1). Moreover, the candidate genes were selected based on previous studies that have shown that the deletion of these genes affect cobalamin biosynthesis in other bacterial species $[47,50,51]$. We also evaluated the transcriptional response of eut $V$, a transcriptional regulator of the ethanolamine operon. $\operatorname{csoR}$ (lmo1854), a gene that encodes a transcription factor that regulates $\mathrm{Cu}$ homeostasis in L. monocytogenes, was used as a control to sense for copper exposure [36].

The expression level of these genes was evaluated in response to cold and copper. For this, a fresh TSBYe medium was inoculated with List2-2 adapted to low temperature and incubated at $8{ }^{\circ} \mathrm{C} / 160 \mathrm{rpm}$ to reach an early-log phase $\left(\mathrm{OD}_{600 \mathrm{~nm}}: 0.4\right)$. Then the medium was supplemented with a sub-inhibitory concentration of copper $\left(\mathrm{CuSO}_{4} \times 5 \mathrm{H}_{2} \mathrm{O}\right) 0.5 \mathrm{mM}$ and incubated at $8{ }^{\circ} \mathrm{C} / 160 \mathrm{rpm}$ under aerobic conditions. This copper concentration was used because it is non-lethal for L. monocytogenes but significantly increases the copper cellular content [36]. Samples were taken at 0 (before adding copper; the control condition), 1, 6, and $24 \mathrm{~h}$ for RNA extraction. RNA was extracted using the NucleoZOL reagent (Macherey-Nagel, Düren, Germany) according to the manufacturer's recommendations. Complementary DNA (cDNA) synthesis was carried out from $1 \mu \mathrm{g}$ of RNA with the reverse transcriptase enzyme MMLV-RT (Moloney Murine Leukemia Virus Reverse Transcriptase; Promega, Madison, WI, USA). Primers were designed with the Primer-BLAST tool using the genome of L. monocytogenes List2-2 as a template (Additional file 2: Table S1). SYBR Green Agilent Master Mix enzyme (Agilent Technologies, Santa Clara, CA, USA) was used for qPCR amplification according to the manufacturer's instructions. The qPCR conditions were an initial denaturation at $95^{\circ} \mathrm{C}$ for $10 \mathrm{~min}$, followed by 40 cycles of denaturation $\left(95^{\circ} \mathrm{C}\right.$ for $\left.30 \mathrm{~s}\right)$, annealing $\left(60{ }^{\circ} \mathrm{C}\right.$ for $\left.60 \mathrm{~s}\right)$, and extension $\left(72{ }^{\circ} \mathrm{C}\right.$ for $30 \mathrm{~s}$ ). Real-time PCR (qPCR) reactions were performed in the Agilent AriaMx Real-Time PCR system in a final reaction volume of $10 \mu \mathrm{l}$.

The relative abundance level of each evaluated transcript was compared at time zero to the other times tested and was calculated using the $2^{-(\Delta \Delta \mathrm{Ct})}$ method proposed by Livak and Schmittgen [52]. The 16S rRNA gene (lmor04) was used as housekeeping $[36,53]$. The qPCR reaction for each gene was performed in three biological replicates with two technical replicates each.

\section{Generation of $\Delta c b i P$ mutant strain}

$c b i P$ was one of the genes that showed the highest expression levels in response to the stress condition in the study $\left(8{ }^{\circ} \mathrm{C}+\right.$ copper $)$. It has been observed that its deletion affects the synthesis of cobalamin in other microorganisms [47]. Therefore, we evaluated the effect of the absence of a gene that encodes for CbiP in the tolerance to low temperature + copper in L. monocytogenes List22. A cbiP mutant was created with homologous recombination using a previously described protocol [54]. The vector pKSV7 was kindly provided by Dr. Rychli from the University of Veterinary Medicine, Vienna. The recombinant fragment (FP) was designed by SOE-PCR using primers detailed in Additional file 2: Table S1. Briefly, the fragment was inserted into the vector pKSV7 (pKSV7FP). Electrocompetent L. monocytogenes List2-2 cells were transformed by adding $3 \mu \mathrm{g}$ of the vector pKSV7-FP using the following electroporation parameters: $2.5 \mathrm{kV}$, 
200 Ohms, $25 \mu \mathrm{F}$ in a BioRad Gene Pulser X Cell electroporator (Biorad, Hercules, CA, USA). Multiple passages of transformed cells were performed at $40{ }^{\circ} \mathrm{C}$ in Trypticase Soy Broth (TSBYe) supplemented with chloramphenicol $(10 \mu \mathrm{g} / \mathrm{mL})$ to induce vector insertion. Vector excision was induced by cell passages in BHI broth at $30{ }^{\circ} \mathrm{C}$ without antibiotics. Possible mutants were first screened by PCR (primers cbiP_L_F-LV and cbiP_R_R$\mathrm{LV}$, Table 1), then the junction area was sequenced for confirmation.

\section{Mutant strain evaluation: tolerance to low temperature + copper}

Overnight cultures of wild-type and List2-2 $\Delta c b i P$ were diluted ten-fold to analyze their growth in agar. A volume of $10 \mu \mathrm{L}$ from the $10^{-4}$ to the $10^{-6}$ dilutions were inoculated on TSAYe agar plates supplemented with 1 and $3 \mathrm{mM} \mathrm{CuSO}_{4} \times 5 \mathrm{H}_{2} \mathrm{O}$. Copper-free TSAYe agar was used as a control. A $10 \mu \mathrm{L}$ volume from the $10^{-4}$ to $10^{-7}$ dilutions was also inoculated in plates supplemented with $5 \mathrm{nM}$ of cyanocobalamin (Merck KGaA, Darmstadt, Germany) to test the protective role of cyanocobalamin against the cold + copper stress on L. monocytogenes. All plates were incubated at $8{ }^{\circ} \mathrm{C}$, and the growth was monitored every day for 7 days. Each assay was performed in triplicate.

\section{Statistical analysis}

Statistical analysis was conducted in $\mathrm{R}$ project 4.0.2 [55]. Relative expression data were described as mean \pm standard deviation and all comparisons were performed between times (1, 6, and $24 \mathrm{~h}$ ). Non-parametric KruskalWallis and post hoc Dunn tests were used to analyze the statistical significance between experimental groups. $P$-values $<0.05$ were considered statistically significant.

\begin{abstract}
Abbreviations
L. monocytogenes: Listeria monocytogenes; List2-2: L. monocytogenes Strain; cbiP: A cobyric acid synthase encoding gene; cbiB: A cobalamin biosynthesis encoding gene; cysG: A uroporphyrin-III C-methyltransferase encoding gene; eutV: A transcriptional regulator encoding gene; $\triangle c b i P$ : List2-2 mutant for cbiP gene; PCR: Polymerase chain reaction; qPCR: Quantitative real-time PCR; TSBYe: Trypticase soy broth and yeast extract; $\mathrm{OD}_{600 \mathrm{~nm}}$ : Optical density at $600 \mathrm{~nm}$.
\end{abstract}

\section{Supplementary Information}

The online version contains supplementary material available at https://doi. org/10.1186/s40659-022-00376-4.
Additional file 1: Figure S1. Cobalamin biosynthesis pathway in $L$. monocytogenes. (A) Stages of the cobalamin biosynthesis pathway in $L$. monocytogenes List2-2. Cobalamin biosynthesis can be divided into three stages following the classification of Scott \& Roessner, 2002 [24]. Stage 1: The transformation of Uroporphyrinogen III to Precorrin-2, which is similar for both the anaerobic and the aerobic, and is carried out by the CysG / CobA proteins; Stage 2: This is different for the anaerobic route ( $L$. monocytogenes), where the CysG protein (bifunctional protein) inserts the cobalt ion in the precorrin-2 molecule independently of oxygen. For the aerobic pathway (right side) the cobalt ion is inserted into the molecule by the CobNST complex, and Stage 3: Both pathways (aerobic and anaerobic) converge in cob(II)yrinate a, c diamide which is finally transformed into cobalamin. (B) Arrangement of the cluster of genes involved in cobalamin biosynthesis in L. monocytogenes List2-2 genome. (i) Twenty genes encoded in a cluster of 16870 bp; (ii) Two genes of the cobalamin biosynthetic pathway encoded in the propanediol operon.

Additional file 2: Table S1. Primers used in this study.

\section{Acknowledgements}

Not applicable.

\section{Authors' contributions}

LV, AR-J: Conceptualization of the study. LV, AP, AQ-V: qPCR experiments. LV, GG: Mutant construction and characterization. LV, PN, MT, ML, MG, AR-J: Writing — original draft preparation. LV, AP, MG, AR-J: Writing, reviewing, and editing. All authors read and approved the final manuscript.

\section{Funding}

ENLACE ENL12/20. Center for Mathematical Modeling, Grant/Award Number: AFB170001; FONDECYT N 1190742; Center for Genome Regulation ANID/

FONDAP/15200002; CUECH; Gobierno Regional Chile

Availability of data and materials

Not applicable

\section{Declarations}

Ethics approval and consent to participate

Not applicable

\section{Consent for publication}

Not applicable

\section{Competing interests}

The authors declare that they have no competing interests

\section{Author details}

${ }^{1}$ Laboratorio de Microbiología y Probióticos, INTA Universidad de Chile, Avenida El Líbano 5524 Macul, Santiago, Chile. ²Doctorado en Acuicultura, Programa Cooperativo Universidad de Chile, Universidad Católica del Norte, Pontificia Universidad Católica de Valparaíso, Valparaíso, Chile. ${ }^{3}$ Facultad de Ciencias del Mar, Universidad Católica del Norte, Larrondo 1281, Coquimbo, Chile. ${ }^{4}$ Laboratorio de Bioingeniería, Instituto de Ciencias de la Ingeniería, Universidad de O'Higgins, Rancagua, Chile. ${ }^{5}$ ANID-Millennium Science Initiative Program-Millennium Nucleus in the Biology of the Intestinal Microbiota, Santiago, Chile. ${ }^{6}$ Laboratorio de Bioinformática y Expresión Génica, INTA, Universidad de Chile, Santiago, Chile. ${ }^{7}$ Fondap Center for Genome Regulation (CGR), Santiago, Chile.

Received: 17 September 2021 Accepted: 24 January 2022 Published online: 02 March 2022

\section{References}

1. Torgerson PR, Devleesschauwer B, Praet N, Speybroeck N, Willingham AL, Kasuga F, et al. World Health Organization estimates of the global and regional disease burden of 11 foodborne parasitic diseases, 2010: a data synthesis. PLoS Med. 2015;12(12):e1001920. 
2. Huang JY, Henao OL, Griffin PM, Vugia DJ, Cronquist AB, Hurd S, et al. Infection with pathogens transmitted commonly through food and the effect of increasing use of culture-independent diagnostic tests on surveillance-foodborne diseases active surveillance network, 10 U.S. Sites, 2012-2015. MMWR Morb Mortal Wkly Rep. 2016;65(14):368-71.

3. Powell MR. Trends in reported foodborne illness in the United States; 1996-2013. Risk Anal. 2016;36(8):1589-98.

4. Ferreira V, Wiedmann M, Teixeira P, Stasiewicz MJ. Listeria monocytogenes persistence in food-associated environments: epidemiology, strain characteristics, and implications for public health. J Food Prot. 2014;77(1):150-70.

5. Buchanan R, Gorris L, Hayman M, Jackson TC, Whiting RC. A review of Listeria monocytogenes: an update on outbreaks, virulence, dose-response, ecology, and risk assessments. Food Control. 2017;75:13.

6. Thakur M, Asrani RK, Patial V. Chapter 6 - Listeria monocytogenes: a foodborne pathogen. In: Holban AM, Grumezescu AM, editors. Foodborne Diseases. Cambridge: Academic Press; 2018. p. 157-92.

7. Schlech WF. Epidemiology and clinical manifestations of Listeria monocytogenes infection. Microbiol Spectr. 2019;7(3):7.

8. Barria C, Malecki M, Arraiano CM. Bacterial adaptation to cold. Microbiology. 2013;159(Pt 12):2437-43.

9. Gandhi M, Chikindas ML. Listeria: a foodborne pathogen that knows how to survive. Int J Food Microbiol. 2007;113(1):1-15.

10. Piveteau P, Depret G, Pivato B, Garmyn D, Hartmann A. Changes in gene expression during adaptation of Listeria monocytogenes to the soil environment. PLoS ONE. 2011;6(9):e24881.

11. Whitman KJ, Bono JL, Clawson ML, Loy JD, Bosilevac JM, Arthur TM, et al. Genomic-based identification of environmental and clinical Listeria monocytogenes strains associated with an abortion outbreak in beef heifers. BMC Vet Res. 2020;16(1):70.

12. Rodas-Suárez OR, Flores-Pedroche JF, Betancourt-Rule JM, QuiñonesRamírez El, Vázquez-Salinas C. Occurrence and antibiotic sensitivity of Listeria monocytogenes strains isolated from oysters, fish, and estuarine water. Appl Environ Microbiol. 2006;72(11):7410-2.

13. Weller D, Wiedmann M, Strawn LK. Irrigation is significantly associated with an increased prevalence of Listeria monocytogenes in produce production environments in New York State. J Food Prot. 2015;78(6):1132-41.

14. Bucur Fl, Grigore-Gurgu L, Crauwels P, Riedel CU, Nicolau Al. Resistance of Listeria monocytogenes to stress conditions encountered in food and food processing environments. Front Microbiol. 2018;9:2700.

15. Kallipolitis B, Gahan CGM, Piveteau P. Factors contributing to Listeria monocytogenes transmission and impact on food safety. Curr Opin Food Sci. 2020;36:9-17.

16. Tan X, Chung T, Chen Y, Macarisin D, LaBorde L, Kovac J. The occurrence of Listeria monocytogenes is associated with built environment microbiota in three tree fruit processing facilities. Microbiome. 2019;7(1):115.

17. Fang $\mathrm{H}$, Kang J, Zhang D. Microbial production of vitamin B(12): a review and future perspectives. Microb Cell Fact. 2017;16(1):15.

18. Gruber K, Puffer B, Kräutler B. Vitamin B12-derivatives-enzyme cofactors and ligands of proteins and nucleic acids. Chem Soc Rev. 2011:40(8):4346-63.

19. Kräutler B. Vitamin B12: chemistry and biochemistry. Biochem Soc Trans. 2005;33(Pt 4):806-10.

20. Roth JR, Lawrence JG, Bobik TA. Cobalamin (coenzyme B12): synthesis and biological significance. Annu Rev Microbiol. 1996:50:137-81.

21. Warren MJ, Raux E, Schubert HL, Escalante-Semerena JC. The biosynthesis of adenosylcobalamin (vitamin B12). Nat Prod Rep. 2002;19(4):390-412.

22. Raux E, Lanois A, Levillayer F, Warren MJ, Brody E, Rambach A, et al. Salmonella typhimurium cobalamin (vitamin B12) biosynthetic genes: functional studies in S. typhimurium and Escherichia coli. J Bacteriol. 1996;178(3):753-67.

23. Rodionov DA, Vitreschak AG, Mironov AA, Gelfand MS. Comparative genomics of the vitamin B12 metabolism and regulation in prokaryotes. J Biol Chem. 2003;278(42):41148-59.

24. Scott Al, Roessner CA. Biosynthesis of cobalamin (vitamin B(12)). Biochem Soc Trans. 2002;30(4):613-20.

25. Ferrer A, Rivera J, Zapata C, Norambuena J, Sandoval Á, Chávez R, et al. Cobalamin protection against oxidative stress in the acidophilic iron-oxidizing bacterium Leptospirillum group II CF-1. Front Microbiol. 2016;7:748.
26. Anast JM, Bobik TA, Schmitz-Esser S. The cobalamin-dependent gene cluster of Listeria monocytogenes: implications for virulence, stress response, and food safety. Front Microbiol. 2020;11:601816.

27. Anast JM, Schmitz-Esser S. The transcriptome of Listeria monocytogenes during co-cultivation with cheese rind bacteria suggests adaptation by induction of ethanolamine and 1,2-propanediol catabolism pathway genes. PLoS ONE. 2020;15(7):e0233945.

28. Tang S, Orsi RH, den Bakker HC, Wiedmann M, Boor KJ, Bergholz TM. Transcriptomic analysis of the adaptation of Listeria monocytogenes to growth on vacuum-packed cold smoked salmon. Appl Environ Microbiol. 2015;81(19):6812-24

29. Parra A, Toro M, Jacob R, Navarrete P, Troncoso M, Figueroa G, et al. Antimicrobial effect of copper surfaces on bacteria isolated from poultry meat. Braz J Microbiol. 2018;49(Suppl 1):113-8.

30. Wilks SA, Michels HT, Keevil CW. Survival of Listeria monocytogenes Scott A on metal surfaces: implications for cross-contamination. Int J Food Microbiol. 2006;111(2):93-8

31. Hans M, Mathews S, Mücklich F, Solioz M. Physicochemical properties of copper important for its antibacterial activity and development of a unified model. Biointerphases. 2015;11(1):018902.

32. Li C, Li Y, Ding C. The role of copper homeostasis at the host-pathogen axis: from bacteria to fungi. Int J Mol Sci. 2019;20(1):175.

33. Giachino A, Waldron KJ. Copper tolerance in bacteria requires the activation of multiple accessory pathways. Mol Microbiol. 2020;1 14(3):377-90

34. Reyes-Jara A, Latorre M, López G, Bourgogne A, Murray BE, Cambiazo V, et al. Genome-wide transcriptome analysis of the adaptive response of Enterococcus faecalis to copper exposure. Biometals. 2010;23(6):1105-12.

35. Latorre M, Quesille-Villalobos AM, Maza F, Parra A, Reyes-Jara A. Synergistic effect of copper and low temperature over Listeria monocytogenes. Biometals. 2015;28(6):1087-92.

36. Quesille-Villalobos AM, Parra A, Maza F, Navarrete P, González M, Latorre $M$, et al. The combined effect of cold and copper stresses on the proliferation and transcriptional response of Listeria monocytogenes. Front Microbiol. 2019;10:612.

37. Cordero N, Maza F, Navea-Perez H, Aravena A, Marquez-Fontt B, Navarrete $P$, et al. Different transcriptional responses from slow and fast growth rate strains of Listeria monocytogenes adapted to low temperature. Front Microbiol. 2016;7:229

38. Shelton AN, Seth EC, Mok KC, Han AW, Jackson SN, Haft DR, et al. Uneven distribution of cobamide biosynthesis and dependence in bacteria predicted by comparative genomics. ISME J. 2019;13(3):789-804.

39. Watanabe F, Bito T. Vitamin B(12) sources and microbial interaction. Exp Biol Med. 2018;243(2):148-58.

40. Balabanova L, Averianova L, Marchenok M, Son O, Tekutyeva L. Microbial and genetic resources for cobalamin (Vitamin B12) biosynthesis: from ecosystems to industrial biotechnology. Int J Mol Sci. 2021;22(9):4522.

41. Ahn AC, Jongepier E, Schuurmans JM, Rijpstra WIC, Sinninghe Damsté JS, Galinski EA, et al. Molecular and physiological adaptations to low temperature in Thioalkalivibrio strains isolated from soda lakes with different temperature regimes. mSystems. 2021;6(2):e01202.

42. Ahn AC, Cavalca L, Colombo M, Schuurmans JM, Sorokin DY, Muyzer G. transcriptomic analysis of two Thioalkalivibrio species under arsenite stress revealed a potential candidate gene for an alternative arsenite oxidation pathway. Front Microbiol. 2019;10:1514.

43. Fox EM, Leonard N, Jordan K. Physiological and transcriptional characterization of persistent and nonpersistent Listeria monocytogenes isolates. Appl Environ Microbiol. 2011;77(18):6559-69.

44. Casey A, Fox EM, Schmitz-Esser S, Coffey A, McAuliffe O, Jordan K. Transcriptome analysis of Listeria monocytogenes exposed to biocide stress reveals a multi-system response involving cell wall synthesis, sugar uptake, and motility. Front Microbiol. 2014;5:68.

45. Mellin JR, Koutero M, Dar D, Nahori MA, Sorek R, Cossart P. Riboswitches, Sequestration of a two-component response regulator by a riboswitchregulated noncoding RNA. Science. 2014;345(6199):940-3.

46. Kipkorir T, Mashabela GT, de Wet TJ, Koch A, Wiesner L, Mizrahi V, et al. De novo cobalamin biosynthesis, transport, and assimilation and cobalaminmediated regulation of methionine biosynthesis in Mycobacterium smegmatis. J Bacteriol. 2021;203(7):e00620.

47. Woodson JD, Zayas CL, Escalante-Semerena JC. A new pathway for salvaging the coenzyme B12 precursor cobinamide in archaea requires 
cobinamide-phosphate synthase (CbiB) enzyme activity. J Bacteriol. 2003;185(24):7193-201.

48. Fresquet $V$, Williams $L$, Raushel FM. Partial randomization of the four sequential amidation reactions catalyzed by cobyric acid synthetase with a single point mutation. Biochemistry. 2007:46(49):13983-93.

49. Bubert A, Köhler S, Goebel W. The homologous and heterologous regions within the iap gene allow genus- and species-specific identification of Listeria spp. by polymerase chain reaction. Appl Environ Microbiol. 1992;58(8):2625-32

50. Koyama M, Katayama S, Kaji M, Taniguchi Y, Matsushita O, Minami J, et al. A Clostridium perfringens hem gene cluster contains a cys $G(B)$ homologue that is involved in cobalamin biosynthesis. Microbiol Immunol. 1999:43(10):947-57.

51. Zayas CL, Claas K, Escalante-Semerena JC. The CbiB protein of Salmonella enterica is an integral membrane protein involved in the last step of the de novo corrin ring biosynthetic pathway. J Bacteriol. 2007;189(21):7697-708.

52. Livak KJ, Schmittgen TD. Analysis of relative gene expression data using real-time quantitative PCR and the 2(-Delta Delta C(T)) Method. Methods. 2001;25(4):402-8

53. Tasara T, Stephan R. Evaluation of housekeeping genes in Listeria monocytogenes as potential internal control references for normalizing mRNA expression levels in stress adaptation models using real-time PCR. FEMS Microbiol Lett. 2007;269(2):265-72.

54. Rychli K, Guinane CM, Daly K, Hill C, Cotter PD. Generation of nonpolar deletion mutants in Listeria monocytogenes using the "SOEing" Method. In: Jordan K, Fox EM, Wagner M, editors. Listeria monocytogenes: methods and protocols. New York: Springer; 2014. p. 187-200.

55. R Core Team. A language and environment for statistical computing. R Foundation for Statistical Computing, Vienna, Austria. URL https://www.Rproject.org/.

\section{Publisher's Note}

Springer Nature remains neutral with regard to jurisdictional claims in published maps and institutional affiliations.

- fast, convenient online submission

- thorough peer review by experienced researchers in your field

- rapid publication on acceptance

- support for research data, including large and complex data types

- gold Open Access which fosters wider collaboration and increased citations

- maximum visibility for your research: over $100 \mathrm{M}$ website views per year

At BMC, research is always in progress.

Learn more biomedcentral.com/submissions 